\title{
EL LEGADO ÁRABE DE LA ÉPICA HISPÁNICA
}

En la segunda mitad del siglo IX eran conocidos en alAndalus los héroes islámicos, sus hazañas y la poesía que las cantaba. En el siglo $\mathrm{X}$ este conocimiento era general: la poesía preislámica; los ayyam al-carab 'días de los árabes', recopilación en prosa y verso de las luchas de las tribus primitivas; la hamasa, comentada en suelo ibérico en la obra de Abu-Hayyay al Alam de Santa María del Algarbe (1083), comentarista también de las mualacas, las célebres odas preislámicas; los héroes que serían famosos en todo el mundo musulmán y que todavía hoy llenan con sus hazañas buena parte del repertorio de los bardos populares - rawíes - como Antara, como Qays, fueron tan conocidos en al-Andalus como en cualquier otro territorio árabel. Para cualquier conocedor del enorme peso que esta poesía guerrera, estas hazañas, tienen en el mundo musulmán, resulta imposible pensar que al-Andalus hubiera podido ser distinto. Los pueblos de España, que tan rápidamente y bien asimilaron los valiosos elementos culturales que aportaba al-Andalus, que recogieron para Europa tanta riqueza de ciencia y pensamiento, desde las tablas astronómicas hasta la escatología, no pudieron ser insensibles al latido épico que esta poesía encierra. La constante relación entre cristianos y musulmanes, la emulación despertada por los repetidos enfrentamientos - que alcanzará en el romancero morisco cotas de insospechada gallardía-, todo tenía que contribuir a que la presencia árabe en la épica hispánica primitiva no se limitara al decorado, sino que fuese mucho más profun$\mathrm{da}$, hasta calar en motivos e influencias que hacen imprescindible el elemento árabe para comprender la génesis de la épica románica medieval. El mejor conocimiento que hoy tenemos de cómo los moriscos se encargaron de traducir y conservar la épica árabe - desarrollando la importancia de personajes, como Alí,

${ }^{1}$ LUTFI ABDEL BADI, La épica árabe y su influencia en la épica castella$n a$, Santiago de Chile, 1964, p. 43. 
en el filo de la heterodoxia -, nos permite suponer que incluso quienes no entendían la lengua árabe que los rawíes o recitadores utilizaran (y que suponemos, como hoy, adaptada a la variedad hablada local) podían conocer, en el romance de las traducciones moriscas, la épica de Oriente ${ }^{2}$.

No vamos a volver aquí a la discusión de si hay una épica árabe, si ésta es o no de tipo occidental - en lo cual se incurre en contrasentido-, si se trata de una poesía narrativa, carente de la construcción formulaica propia de la épica, para no dar más vueltas a la entrada del temas. Nos basta, en realidad, con afirmar que existe una poesía narrativa árabe, que hay una "materia épica" árabe, y que el conocimiento de ella en al-Andalus es determinante de su influencia en la formación de la épica románica.

La vieja teoría que veía en la épica castellana una simple continuación de la francesa, hace mucho tiempo que carece de toda validez; queda reducida simplemente al hecho de que, del mismo modo que en los poemas franceses aparecen gran cantidad de elementos hispánicos, también en la épica castellana - como en toda la vida española, especialmente en los siglos XI y XII - están presentes una serie de elementos franceses, simple prueba del intenso contacto entre las dos culturas.

La tesis latina, que en planteamientos precedentes, de García Gallo y de Chiri, por ejemplo, había sufrido importantes refutaciones, ha sido replanteada por $\mathrm{H}$. Salvador Martínez ${ }^{4}$, a partir de criterios bastante discutibles (e incluso erróneos, como la aplicación de criterios métricos inadecuados a la hora de medir la poesía latina medieval, desconociendo que ésta no sigue la norma clásica, y que es preciso introducir criterios correctores). Para los partidarios de esta tesis alcanzarían valor de testimonio sobre la existencia de una épica latina vulgar de raros vestigios, mientras que, por otra parte, el hecho de que la poesía épica latina medieval - no vulgar - única verdaderamente testiguada, como el Waltharius, o el poema In honorem Hludowici de Er-

${ }^{2}$ ÁLVARo Galmés DE FUENTES, El "Libro de las batallas", Universidad de Oviedo, 1967. Una fundamental antología de la literatura aljamiada es la de REINHOLD KONTZI, Aljamiadotexte, 2 ts. Wiesbaden, 1974.

${ }^{3}$ Cf. ABDEL BADI, op. cit., y F. MARcos MARÍN, Poesia narrativa árabe y épica hispánica, Madrid, 1971, y "Vividura hispánica y poesía épica árabe", en Estudios sobre la obra de Américo Castro, Madrid, 1971, pp. 303-328.

${ }^{4}$ ALFonso GaRcía Gallo, El carácter germánico de la épica y el derecho en la Edad Media española, Madrid, 1955; G. CHIRI, L'epica latina medievale e la Chanson de Roland, Génova, 1936; H. SALVADOR MARTÍNEZ, El "Poema de Almería" y la épica románica, Madrid, 1975. 
moldo, sea un muestrario de sabiduría clásica (lo que parece claro) carecería de importancia. Bien podrían darse vuelta estos argumentos, tal como los presenta $\mathrm{H}$. Salvador, y, en lugar de defender que poemas tardíos (siglo XII), como el de Almería, muestren una evolución de la épica latina para adaptarse al pueblo - a partir de lo cual se postula un influjo latino en los poemas romances - , habría que decir que son precisamente estos últimos los que hacen que la poesía latina abandone, de vez en cuando, su elevada esfera: no se origina la épica romance desde una épica latina vulgar, sino que, a veces, la épica en latín se vulgariza para acercarse al éxito de la románica, y a su público, que es lo contrario de lo que se dice. Esto, por supuesto, no significa que no se adviertan huellas de la literatura latina en la canción de gesta - como en toda la literatura romance. Tras la obra literaria hay un autor, y en éste se dan las influencias propias de su universo cultural.

La tesis germánica, en cambio, ha sido básica para los orígenes de la épica castellana ${ }^{5}$. Indudablemente, es necesaria para explicar, al menos en parte, los de la epopeya francesa, y, ciertamente, hay un importante número de temas de las gestas y el romancero (Don Bueso, por ejemplo ${ }^{6}$ ), que dependen de antecedentes germánicos. Sin embargo, conviene hacer algunas puntualizaciones: no cabe duda de que los visigodos estaban mucho más romanizados que los francos, las referencias a su historia peninsular son escasas, y también lo son las que hablan de su posible épica. Se ha puesto de manifiesto el carácter posiblemente latino de alguna de las instituciones que se les atribuyen, y lo mismo podría ocurrir en relación con el árabe. Indudablemente, sin el poso germánico no habría épica románica; pero sólo con él, creemos, no tendríamos la realidad que hoy nos ocupa.

Así, se ha hablado del carácter germánico de la leyenda de la liberación de Castilla por el precio de un caballo (y un azor); pero ha bastado una revisión de fuentes ${ }^{7}$ para comprobar que, una vez más, no es oro todo lo que reluce.

En el año 927, el conde Fernán González, a su pesar, según nos dice la Primera Crónica General, hubo de ir a las cortes con-

${ }^{5}$ Cf. RAMÓN MENÉNdez PIDAL, De primitiva lírica española y antigua épica, Buenos Aires, 1951; Los godos y la epopeya española, Madrid, 1956; La Chanson de Roland y el neotradicionalismo, Madrid, 1959.

${ }^{6}$ Cf. R. MEnéndez Pidal, Los godos, pp. 89-173; F. Marcos Marín, "Una encuesta romancística en zona astur-leonesa", en Estudios y trabajos del seminariu de llingua asturiana, t. 2, Oviedo, pp. 107-120.

${ }^{7}$ Cf. LeONARD PATRICK HARVeY, "Fernán González's horse", $H R H$, 77-86. 
vocadas por el rey Sancho en León. El rey leonés se prendó del caballo que el castellano había ganado en la de Almanzor, y de su azor mudado. Tras una discusión sobre si el rey compra el caballo o el conde se lo regala, triunfa el parecer del rey, y el caballo se vende por mil marcos de plata, con fecha fija de pago, y al gallarín, lo que se interpreta como doblados cada día tras esa fecha. El rey, luego, demoró el pago, y cuando hubieron de hacerse las cuentas era ya imposible reunir la cantidad resultante: la independencia de Castilla como precio fue la única solución.

El Poema de Fernán González y la PCG coinciden en los detalles. El contexto nos sitúa ante una roboratio: una donación comporta un alboroque, o robra. Ésta es, en efecto, la primera interpretación de la críticá ${ }^{8}$, apoyada en la documentación de la época": "En la Edad Media el que recibía una donación entregaba en cambio al donante cualquier objeto de pequeño valor para dar a la donación, en vez de su carácteŕ de acto gratuito, el indispensable carácter de una compra o de un cambio, y a esto se llamaba roboratio o corroboración. Los objetos usuales para esta roboratio eran muchos: una pequeña suma de dinero, un par de guantes, una capa, cierta cantidad de vino o de trigo, una mula, un caballo, un azor. El caballo y el azor juntos se hallan sirviendo de roboratio en varios documentos de los siglos X y XI, y podemos suponer que sirvieron para una donación, verdadera o apócrifa, en que el rey de León cediese a Fernán González varios derechos sobre el condado, por lo cual pudo decirse que el rey había cedido el condado a cambio de un caballo y un azor" 10 .

William J. Entwistle, en 1924"1, relacionó el tema del caballo y el azor con el relato de Jordanes en el que se nos cuenta la liberación de un pueblo por el precio de un caballo, en la sección 38 de su Getica $a^{12}$. El investigador inglés concluye señalando que es "provechoso reunir los que parecen ser los dos únicos usos de este motivo narrativo concreto".

${ }^{8} \mathrm{R}$. MENÉNDEZ PIDAL, La epopeya castellana a través de la literatura española, Madrid, 1974 (la versión francesa original es de 1910).

${ }^{9} \mathrm{R}$. MENÉNDEZ PIDAL, La epopeya, pp. 47-48.

${ }^{10}$ El halcón y el caballo juntos, como producto de España, aparecen ya en el falso Abencotaiba, p. 123: "Trajo consigo Muza innumerables muestras de todas las producciones naturales de España, tales como halcones, mulas, caballos, esclavos, frutos y toda especie de curiosidades o rarezas".

11 "The liberation of Castile", MLR, 19 (1924), 471-472.

${ }^{22}$ Cf. THEODOR MOMMSEN, Monumenta Germaniae historica, t. V, pars prior. Berlin, edidit Societas Aperiendis Fontibus Rerum Germanicorum Medii Aevi, Auctorum Antiquissorum, 1882. 
En 1955, Menéndez Pidal ${ }^{13}$ recoge en Spoleto el dato de Entwistle - que también aparece incorporado en la versión española de La epopeya castellana a través de la literatura española - , lo despoja de las dudas del profesor británico y lo considera "un tema de los godos de Oriente que sobrevive en España", título precisamente del capitulillo en cuestión.

La crítica posterior ha aceptado sin más la solución del maestro de hispanistas, y así hay quien dice tranquilamente"4: "Sabemos ahora que esta forma inusitada de obtener su libertad un pueblo es una viejísima tradición gótica, recogida por Jordanes en su Getica en el siglo VI".

L. P. Harvey, en 1976, nos obliga, sin embargo, a volver las cosas a su sitio. Veamos, de acuerdo con este autor, el texto conflictivo, en primer lugar ${ }^{15}$ :

Hunuguri autem hinc sunt noti quia ab ipsis pellium murinarum venit commercium QUOS tantorum virorum formidavit audacia. QUORUM mansione prima in Scythia solo iuxta paludem Meotidem, secundo in Mysiam Thraciamque et Daciam, tertio supra mare Ponticum rursus in Scythia legimus habitasse: nec eorum fabulas alicubi repperimus scriptas, qui eos dicunt in Brittania vel in inaqualibet insularum in servitute redactos et in unius caballi praetio a quodam ereptos, aut certe si quis eos aliter dixerit in nostro urbe, quam quod nos diximus, fuisse exortos, nobis aliquid obstrepebit: nos enim potius lectioni credimus quam fabulis anilibus consentimus.

A partir de los datos que Harvey nos ofrece, vemos así el problema de la interpretación de este texto:

La duda radica en los antecedentes de los relativos quos y quorum. Ya el primer editor, Mommsen, interpretaba que quos eran los Hunuguri, mientras que quorum se refería al sujeto de

${ }^{13}$ Los godos, pp. 43 ss.

${ }^{14}$ J. BAUTista AVAlle-ARCE, "El Poema de Fernán González: clerecía y juglaría", $P h Q, 51$ (1972), 60-73.

${ }^{15}$ En MOMMSEN, op. cit., pp. 63-64, citado por Harvey. He aquí una traducción que sacrifica toda posible elegancia a la literalidad: "Mas los húngaros son conocidos porque de ellos vino el comercio de pieles de armiño, a los cuales teme el valor de muchos hombres. De los cuales leemos que han habitado primero en Escitia, solamente junto a la laguna Meótida, en segundo lugar en Misia, Tracia y Dacia, en tercero sobre el mar Póntico, de nuevo en Escitia: y no hacemos caso a las fábulas escritas acerca de ellos en alguna parte, que hablan de ellos como caídos en esclavitud en Bretaña o en cualquier otra isla, y rescatados por alguien por el precio de un caballo, o ciertamente si alguien dijera en nuestra ciudad que fueron sacados de otro modo que el que hemos dicho, algo nos haría callar: pues nosotros creemos antes a lo que leemos que estamos de acuerdo con cuentos de viejas". 
la acción del libro: los godos ${ }^{16}$. Norbert Wagner ${ }^{17}$ señala que el sentido debe primar sobre la gramática, y que si bien, de acuerdo con ésta, parece que los dos relativos se refieren a los húngaros, la solución radica en el sentido general del texto. Sabemos, en efecto, que es a los godos a los que se sitúa en Escitia, Misia, Tracia y Dacia (más o menos acertadamente) y se atribuye la ubicación en ese vago Bretaña o las islas, de Bretaña o las islas, de modo que parece lógico interpretar que la leyenda del caballo se refiere a ellos ${ }^{18}$.

Menéndez Pidal, que conocía el texto, sacó su propia interpretación, y parece lógico sumarse a ella, por lo que venimos diciendo; sin embargo, no debe olvidarse que se trata de una interpretación plausible, no de una certeza. Harvey insiste en ello, creemos que oportunamente. Este autor señala además un punto importante, siguiendo a Wagner, en el que, al aceptarlo, no aceptamos la segunda parte de la interpretación de don Ramón: la historia de la libertad de los godos a cambio de un caballo, y el apodo de got $i$, que en nórdico antiguo significa 'caballos', referido a ellos, son motes insultantes, y no exaltaciones del orgullo nacional. También nos parece muy plausible (aunque sin comprobar) la puntualización de Wagner, que Harvey recoge, de que la progresión geométrica del precio en el $P F G$ parece más propia de un cuento árabe, por su base matemática, que de una leyenda bárbara. Desde luego, que de una historia derisoria se haya pasado a un motivo épico nacional es, como dice Wagner ${ }^{19}$, "impensable".

Harvey ${ }^{20}$ apunta, marginalmente, a las narraciones húngaras (lit. tales 'cuentos') en las que se cuenta cómo la Baja Panonia fue ganada al precio de un garañón (o de doce esclavos, camellos, etc., en versiones anteriores). Estos cuentos aparecen en crónicas del siglo XIV, editadas por S. Domanovszky (que nos ha sido imposible consultar), y, al parecer, ya Jacob Bleyer ${ }^{21}$ cree que esos cuentos se remontan a Jordanes. Harvey cree que Bleyer interpretaba que la narración de Jordanes se refería a los húnga-

${ }^{16}$ L. P. HARVEY nos dice que también lo interpreta así, en su traducción, C. C. Mierow, The Gothic history of Jordanes, Princeton, 1915.

${ }^{17}$ Getica: Untersuchungen zum Leben des Jordanes und zur frühen Geschichte der Goten, Berlin, 1967, cap. 2, citado por Harvey.

${ }^{18}$ Getica, sección 39.

${ }^{19}$ Getica, p. 101.

${ }^{20}$ Art. cit., p. 86.

21 "Germanische Elemente der ungarischen Hunnersage", BGDS, t. 31, 429-599 cit. por Harvey. Cf. también SÁNDOR DomANovszky, A magyar $k i$ rálykrónika xiv. századi folytatása, Budapest, 1934. 
ros, no a los godos; pero, sin discutir con él si efectivamente Bleyer creía o no esto, nos parece que lo importante es que, con la ambigüedad del texto de Jordanes, cualquiera pudo entenderlo así, creándose una tradición histórica que arrancaría de esa interpretación, y se plasmaría en el XIV en las crónicas húngaras. También pudo, desde luego, ocurrir otra cosa: la leyenda de la libertad de un pueblo por el precio de un caballo pudo llegarles a los godos en Escitia, y sumarse a su acervo cultural por otra interpretación, tal vez una etimología popular. El terreno es, pues, bastante más resbaladizo.

La oportuna nota de Harvey termina haciendo una referencia a la postura crítica ante el germanismo de la épica castellana, y a la tesis arabista renovada, en la que, implícitamente, alude al autor de estas páginas. Su observación es oportuna, pues, efectivamente, hay cierto material oriental que puede ponerse en relación con esta leyenda, tal como la narran el $P F G$ y la $P C G$; a él nos referimos en apoyo de esta tesis.

Hace pocos años ${ }^{22}$ aparecieron en la iglesia parroquial de Oña unas ricas telas califales. Se encontraron en la parte alta del retablo de la iglesia, precisamente donde se conservan los restos de la infanta Trigidia, bisnieta de Fernán González; parece que se trataba de una tela arrinconada detrás de un arcón. En total son tres piezas: una larga túnica $(1.36 \times 1.05 / 0.85)$ y otras dos piezas menores $(0.45 \times 0.75$ y $0.35 \times 0.32)$; el estado de conservación es bueno, los bordados están hechos con hilo de oro y sedas sobre lino fino, y la policromía se basa en rojo, azul, verde y negro. La pieza mayor parece una amplia túnica. Hay tres inscripciones, una elegante, cúfica, en seda negra, y dos sencillas, en seda roja. En la tela principal ${ }^{23}$ hay círculos con flores tetrafolias, escenas de caza, variedad de animales y una figura humana (con la importancia que ello pueda tener), y hay también, repetido cuatro veces, un azor que descansa sobre la grupa de un caballo. En principio, se pensó en una fecha de finales del XI "o primeros lustros del siglo XII" ${ }^{24}$, para preferirse luego una fecha

22 AGUSTÍN LĀZARO LóPEZ, "Una riquísima tela, quizá de la época fundacional de Castilla, ha sido encontrada en la Iglesia Parroquial de Oña", Bol. de la Institución Fernán González, Burgos, 1969 núm. 172, 48-53; "Las ricas telas halladas en la Iglesia Parroquial de Oña", ibid., 1969, núm. 173, 394396 , con dos fotografías muy borrosas. Hay una reproducción adecuada en Arte burgalés, Burgos (Caja de Ahorros Municipal), 1976, p. 84.

${ }^{28}$ Tras muchas dificultades, conseguí fotografiar personalmente esta bellísima tela. Las afirmaciones de A. Lázaro han sido, pues, comprobadas in situ.

${ }^{24}$ A. LÁzARO LóPEZ, "Las ricas telas”, p. 395. 
califal, en el siglo X. Sería un regalo de Hixem II (976-1013) a Sancho Garcés III (1000-1035).

Una fecha tardía (podría comprobarse la fecha de la escritura) sería un eco de la leyenda castellana y argumento fuerte de la tradicionalidad de la materia épica. Ateniéndonos a la fecha califal postulada, en cambio, caben varias conjeturas. Sin descartar, por supuesto, la posibilidad de que el regalo del califa a la corte navarra fuera intencional, parece juicioso, por falta de pruebas, no aferrarse a esta hipótesis. En cambio, parece indudable que el tema azor-caballo se repite en tejidos orientales, aunque no conocemos ninguna tela en la que, como aquí, el azor descanse en la grupa del equino. La representación de escenas de caza es frecuente y detallista. Flemming ${ }^{25}$ reproduce tejidos helenísticos egipcios, de los siglos VI al VII, coptos de Achmin, donde se aprecia perfectamente el ave sobre dos jinetes (escena simétrica). El tema se extiende por todo el Oriente Próximo y Medio, en estos siglos VI-VII, pues también Flemming recoge escenas de caza con aves en Persia, donde aparecen incluso las alcándaras. Los testimonios posteriores son muy abundantes. De la misma época que el hispano-árabe que comentamos sería un jinete persa, en una tela de los siglos $\mathrm{X}-\mathrm{XI}^{26}$, que aparece con un azor en su mano, también como figura simétrica. El motivo es muy duradero: el museo Victoria y Alberto de Londres conserva un encaje español de la segunda mitad del XVI, donde aparecen un personaje a caballo (don Ruxero) y otro a pie, con sendas aves. Y, puesto que hemos hablado de Hungría, señalemos, por ejemplo, que en el Museo de Bellas Artes de Budapest puede verse un relieve del siglo XV, con una pareja de caballeros, uno de los cuales lleva un ave en la mano. No insistiremos en lo común de la representación.

Estos ejemplos, junto a otros muchos, nos permiten ver cómo, desde el siglo VI, al menos, en adelante, los tejidos de Oriente ${ }^{27}$ muestran temas tan naturales de la caza como la combinación del azor y el caballo. El motivo pudiera proceder del Turquestán, y es bien sabido que este tipo de caza es un importante rasgo cultural islámico medieval, aunque no sea privativo de los árabes. Sin embargo, tanto el origen de la leyenda del azor y el caballo como el motivo iconográfico descrito apuntan hacia

${ }^{25}$ ERNST Fleming, Tejidos aríísiticos, t. 4 de ia Biblioteca de Artes Industriales, Barcelona (G. Gili), 1928, láminas 11, 13, 16.

${ }^{26}$ ROMĀN GHIRSHMAN, Irán, partos y sasánidas, Madrid, p. 236.

${ }^{27}$ Monopolio bizantino todavía en la época Omeya, según me comunica amablemente el prof. Dr. Joaquín Vallvé, de la Universidad Complutense. 
Oriente, bien sea en la cuna de los húngaros, bien en zona extrema de la migración al Este de los visigodos, o bien en el arte venatoria de los pueblos islámicos. Por poca fuerza que se dé a los datos que hemos expuesto, parece claro que la explicación germánica no puede ser ya ni única ni suficiente. En el menor de los casos, es decir, en la suposición de que el tejido de Oña hubiera sido hecho ad hoc, sería difícil pensar que los artífices hispanomusulmanes no conocieran las representaciones orientales, y habría que admitir, sin duda, la presencia de materia épica castellana en la corte califal.

Nuestro punto de partida puede irse enunciando de un modo similar a éste: no hay desgajamiento entre lo latino, lo germánico y lo árabe; cada parcela carece de límites precisos, interpenetrándose con las vecinas. Del mismo modo que ninguna persona libre de prejuicios pretende entender hoy al Arcipreste de Hita sólo a partir de la cultura latina, tampoco es posible cargar en la cuenta de la herencia de Roma, o del legado germánico, la épica medieval. Por ello conviene precisar muy detenidamente qué puede ir ofreciendo la llamada teoría arabista, que, en nuestro caso, no pretende ser una tesis excluyeme, sin caer tampoco en el eclecticismo. Aun admirando muy seriamente esfuerzos como el de Abd el Badi, o el de Galmés de Fuentes, quien sigue muy de cerca al anterior y utiliza planteamientos metodológicos nuestros ${ }^{28}$, creemos que es necesario buscar un hilo de Ariadna

${ }^{28}$ Para una matización sobre todo cronológica, donde queda clara nuestra estimación y agradecimiento a L. Abdel Badi y A. Galmés; pero donde también reivindicamos el orden riguroso, cf. F. MARcos MARÎn, "Épica árabe y épica hispánica", en Bol. Asoc. Esp. Orientalistas (BAEO), 15 (1979), 169175 , transcripción de nuestra comunicación a esta asociación en octubre de 1978. El orden cronológico real, teniendo en cuenta los manuscritos que fueron conocidos como tales antes de su publicación, según consta por escrito, es el siguiente: 1915, J. Ribera, discurso de ingreso en la Academia de la Historia; h. 1960, LUFTI ABDEL BADI, La poesía épica en la España musulmana y su influencia en la épica española, tesis doctoral, publicada en 1964 (nota 1, supra); 1967, octubre, A. GALMÉS, El "Libro de las batallas" (supra, nota 2), discurso inaugural del curso en Oviedo; 1968, junio, F. MARCOS MARÍN, "El problema del elemento árabe en los orígenes de la épica española", Memoria de licenciatura, publicada como Estudios épicos en Montreal, 1970; 1969, F. MARCos MARín, "Los orígenes de la épica española", $A O, 19$ (1969), 149-159 (entregado en 1968); 1969, marzo-abril, A. GALMÉS DE FUENTES, "Épica árabe y épica castellana", ponencia en la Academia Nazionale dei Lincei publicada en 1970 y en 1978 como libro, Barcelona, de donde citaremos; 1969, octubre, F. MARCOS MARÍN, Elementos ârabes en los orígenes de la épica hispánica, tesis doctoral, publicada como Poesía narrativa... (supra, nota 3) en 1971; 1975, A. GalmÉs, El "Libro de las batallas" (ed. y est.), Madrid. El 
en este intrincado laberinto, y postulamos para esta función el concepto de modalidad: no nos satisface el parecido aparente, es necesario encontrar la modalidad común. En ese camino nos confesamos cada vez más cerca de la metodología de Ribera, aunque quizá no tanto de sus tesis últimas.

Don Julián Ribera, en 1915, planteó el problema de la épica hispánica en lengua romance (que él, con el anacronismo propio de su época, llamaba épica andaluza romanceada) en una serie de puntos fundamentales. Arrancó de un párrafo de al-Dajira de Ibn Bassam, en donde se habla de la moaxaja y de la poesía árabe vulgar, con empleo de la lengua romance. Este texto, muy importante en lo que concierne al zéjel y a la lírica, sólo por una extrapolación muy peculiar podía servir de punto de partida para una tesis sobre la épica: Ribera lo hizo así, a sabiendas, creyendo que un pueblo con lírica tenía que tener también épica ${ }^{29}$ : "En las nacientes literaturas no suele haber tal separación: si el pueblo canta, lo canta todo. Únicamente cuando se llega a desarrollos superiores, es cuando lo lírico se separa de lo épico".

A renglón seguido, Ribera estaba obligado a discutir una afirmación de Dozy, pues el gran arabista holandés había negado, al parecer, la existencia de una épica árabe, e incluso su posibilidad. Sin embargo, como ha señalado con acierto A. Galmés ${ }^{30}$, el texto de Dozy es más amplio de lo que cita Ribera, y debe entenderse en el contexto de los conocimientos histórico literarios del siglo XIX, con la épica francesa, tan poco histórica y tan dada a lo maravilloso, como casi única muestra del género en el mundo románico, y con predominio de las tesis tradicionalistas románticas. Ribera hizo una completa demostración de que existía una épica árabe, por llamarla así; pero Dozy, en realidad, afirmaba simplemente que "no existe en la literatura árabe una narrativa de invención idealista, que los árabes no narran ficciones, sino que sólo describen lo que ven y comprueban, o relatan hechos tomados de la vida real"si.

prof. Galmés de Fuentes conoció en manuscrito todos los trabajos de Abdel Badi y Marcos, hasta octubre de 1969, con permiso de sus autores; no hubo ocasión de que se diera la recíproca.

${ }^{29}$ Recogido en Disertaciones y opúsculos, Madrid, 1928, p. 104.

${ }^{30}$ Épica árabe, pp. 17-19.

${ }^{31}$ GaLmés, ibid., p. 19. Dozy se refiere a la narrativa, no a todo el elemento fantástico que aparece en otros géneros. En realidad, nos parece, hoy no podría sostenerse su opinión, ni siquiera así limitada. Lo mismo sucede con otras afirmaciones similares, como pudimos estudiar en "Vividura hispánica", citado en nota 3. 
En los orígenes de la literatura andalusí, en el siglo IX, encuentra Ribera un género narrativo o épico que cuadra con su intención: las urchuzas históricas, poemas en metro rechez, con rima del primer hemistiquio y el segundo, donde se cantan episodios como la conquista, con gran cantidad de materia épica, de las que existieron, al menos dos, la de Algazal y la de Temam b. Alcama, perdidas, pero con huellas en la historiografía árabe. Ribera interpretó algunos datos de estos textos, como su nacionalismo, de un modo que la crítica actual precisa con mayor afinamiento ${ }^{32}$; pero, en general, cuando se repasan las leyendas y los temas contenidos en estos poemas, por lo que sabemos, no es difícil suponer que tenían garantizado un éxito momentáneo.

Precisamente en este sentido, que Ribera no podía saber, y Menéndez Pidal no parece haber seguido, las urchuzas permiten un enlace que vincula las dos partes de la Península: nos referimos a la teoría de los cantos historiales. Originalmente, la teoría de los cantos historiales está vinculada a los orígenes germánicos de la épica castellana ${ }^{33}$. Los godos, según testimonios de Amiano Marcelino (siglo IV) o de Jordanes (siglo VI), tenían cantos en alabanza de sus mayores. En la emigración de los visigodos hacia el oeste, por el sur del Danubio, sabemos que, a la muerte de Teodoredo, en la batalla de los Campos Cataláunicos (451) se cantó en su honor, y que hubo cantares sobre el gran rey ostrogodo Teodorico, centro de buena parte de la materia épica germánica.

Más oscuro es el punto de la perduración de estos cantos entre los visigodos hispanos. A pesar de la sequedad informativa de las crónicas visigóticas, y de la falta absoluta de detalles que las caracteriza, Menéndez Pidal afirma ${ }^{84}$ :

Lo dudoso de indicios como éstos [la Historia Gothorum y la Crónica pseudoisidoriana] y la falta de otras noticias cronísticas referentes a la existencia de cantos narrativos entre los godos de España no puede ser apoyo para la antigua hipótesis de Fernando Wolf, suponiendo que los visigodos, muy cristianizados y muy romanizados, habían perdido sus cantos épicos una vez establecidos en la península pirenaica.

Como prueba de supervivencia, presenta la cita isidoriana sobre los Carmina Maiorum, que - dice - "cumplían el alto fin de la historia como maestra de la vida y dignificadora de la moral cívica" ${ }^{35}$. Estos cantos historiales serían típicamente germáni-

${ }^{32} \mathrm{Cf}$. James T. MONRoe, The shuc ubiyya in Al-Andalus, Los Angeles, 1970.

${ }^{33}$ MENÉndeZ PIDAL, Los godos, passim.

${ }^{34}$ Ibid. , p. 24.

${ }^{35}$ MENÉNDEZ PIDAL, La Chanson de Roland, p. 445. 
eos, y así habrían llamado la atención de los historiadores latinos, pues los romanos carecían de esa modalidad de poesía. Los germanos, tras su dispersión, continuaron con esta costumbre en los otros países donde se asentaron, y así los restos del Waldere o el Beowulf son testigos de la épica anglosajona de refundición (siglo VIII), mientras que "el fragmento de la Muerte de Byrthnoth en la batalla de Maldon (año 991) muestra el canto de sucesos tardíos" ${ }^{36}$. El llamado Poeta Sajón atestigua que los francos de la Galia cantaban a los reyes merovingios de los siglos Vly VII, Clodoveos, Teodoricos y Clotarios.

Si los visigodos, más romanizados, habían perdido, al menos parcialmente, la costumbre de los cantos historiales, la llegada de los árabes hubo de ser un buen revulsivo para su renacimiento. Estos últimos, en efecto, disponían de dos géneros: de un lado las urchuzas históricas de las que hablábamos antes, y de otro los ayyam al-carab, a los que tuvimos ocasión de referirnos al principio, género narrativo, en prosa y verso, de tema guerrero, bien conocido en al-Andalus.

Respecto a las urchuzas, no todas se han perdido; conservamos la de Ibn Abd Rabbihi, sobre Abderrahmán III $^{37}$. Este poeta es, precisamente, uno de los más importantes traductores de poesía preislámica, incluyendo esta narrativa, y otros muchos temas de resonancias épicas. En su urchuza se repiten las reminiscencias de las moalacas preislámicas. El elemento culto en esos poemas es muy importante, pues son obras "clásicas", en el peculiar sentido del término árabe, que implica hasta una restricción lingüística (diglósica); ello no obsta para que podamos encontrar en ellas su atractivo literario junto a una importancia sociológica que permita considerarlas cantos historiales, pues la definición de este género no precisa que sus autores sean o no cultos. Algo que debemos a la investigación de tipo individualista es, precisamente, la revalorización de la condición culta de los poetas y sus elementos de composición. Cuando se buscan autores latinos olvidados, como fuentes parciales de los cantares de gesta, no se puede pedir que precisamente un autor tan culto como Ibn Abd Rabbihi, al componer su urchuza, se olvide de ese elemento cultural, que puede llegar a ser un lastre.

${ }^{36}$ Menendez Pidal, Los godos, p. 22.

${ }^{97}$ Traducida al español en F. MARCos MARín, Estudios épicos, y revisada en Poesía narrativa árabe. Simultáneamente, J. T. MONROE la tradujo al inglés en Hispano-Arabic poetry. A student anthology, Los Angeles, 1974, pp. 74-129. 
Nuestra opinión personal, en este sentido, es que, por ahora, es decir, mientras no aparezca un texto épico mozárabe, lo más importante de la tesis de Ribera es haber señalado que los árabes de al-Andalus disponían de materia épica y de cauces formales para manifestarla o expresarla. ¿Por qué se lanzó luego a buscar huellas de una hipotética épica mozárabe? Pues, sencillamente, porque su concepción de España, el talante positivista de su formación, y la búsqueda de la peculiaridad "española" de lo árabe hispánico que ha caracterizado siempre a la escuela de Madrid le llevaron a ello ${ }^{38}$.

También hay que tener en cuenta que Ribera concede gran importancia a los testimonios, abundantes, de que había personas que no hablaban árabe, o de que, además de ésta, se hablaban otras lenguas. Hoy tenemos una idea bastante más compleja: hablamos del haz dialectal andalusí, por un lado, con distintos niveles y normas ${ }^{39}$, nuestras ideas sobre los dialectos mozárabes y las variedades románicas son también más completas ${ }^{40}$, y también la ciencia lingüística (y la sociolingüística) nos permiten hoy calibrar mejor afirmaciones de esta suerte. Por ello, aun comprendiendo que Ribera llegara a creer, lógicamente, que esos hablantes no totalmente arabizados tendrían su literatura, eso no nos autoriza hoy a llegar a la misma conclusión, precisamente porque tendríamos que matizar mucho más respecto a su conocimiento activo o pasivo, sus niveles, y los requisitos pasivos de la creación literaria, en último término. También, justamente por la mayor precisión de nuestra metodología, estamos hoy en condiciones de decir que el intercambio de juglares, el hecho conocido de que al Cid le gustaba que le contaran (¿cantaran?) las hazañas de los héroes preislámicos e islámicos, que hubiera importantes contingentes de guerreros cristianos más o menos temporalmente vinculados a los musulmanes, con su cohorte de juglares y otras diversiones, la notable miniatura de las Cantigas con el juglar moro y el cristiano, uno al lado del otro, todo ello implica una comunicación con unos grados y escalas que permiten afirmar tranquilamente que los temas, los motivos, pasaban de una a otra literatura sin obstáculo lingüístico, y que si no lo

${ }^{38}$ No queremos insinuar con ello que Ribera tuviera prejuicios como los de Simonet, por ejemplo. Las anotaciones de su puño y letra al ejemplar de la Historia de los mozárabes de la Escuela de Estudios Ârabes son prueba indudable de ello.

${ }^{39}$ Cf. FEDERICo CORRIENTE, A grammatical sketch of the Spanish Arabic dialect bundle, Madrid, 1977.

${ }^{40}$ Cf. RAFAel LaPeSA, Historia de la lengua española, $8^{\mathrm{a}}$ ed., Madrid, 1980. 
hacían las formas, eran las más cultas, porque esa misma diferencia lingüística lo impedía; pero no las otras, que ya García Gómez ha hablado repetidamente de una poesía proindiviso.

Por último, Ribera señala también la paradoja de que la épica francesa, más del norte que del sur, se ocupe fundamentalmente de la "materia de España", de la presencia de rasgos que muestran un buen conocimiento de lo que ocurría en nuestra Península, e inicia el fructífero camino de la deformación de palabras árabes en las gestas francesas, como Desramé por Abderrahmán, y otras, alguna explicable hoy por otro origen ${ }^{11}$. Hoy, ninguna persona sensata e informada defiende que la épica castellana proceda directamente de la francesa, por lo que no tiene vigencia parte de la argumentación de partida de Ribera; el fondo, en cambio, sigue en pie: la huella árabe al norte de los Pirineos es mayor y más profunda, en este género, de lo que se esperaría de una relación mediata.

El tema de las leyendas, así como el de los elementos orientales en la cultura hispanoárabe, ha sido detenidamente estudiado por Mahmud Ali Makki ${ }^{42}$, quien, al relacionar las leyendas de la conquista de al-Andalus con sus fuentes tradicionales de Oriente, profundiza en el estudio de las leyendas andalusíes, mostrando el ininterrumpido flujo entre Oriente y al-Andalus, la interpretación de los temas, y la total vinculación con Oriente de la vida andalusí, como se ve concretamente en varios casos. El profesor egipcio dedica más amplitud a la lírica y a la filosofía, pero cimenta de forma detallada y clara las relaciones literarias entre los extremos del mundo islámico.

Más en la línea de las preocupaciones de Ribera, otro investigador egipcio, Lutfi Abd el Badi, en su tesis doctoral, a la que ya hemos tenido ocasión de aludir, establece claramente, con el conocimiento del hablante nativo, las características fundamentales con las que lo épico aparece en la literatura árabe, como pun-

${ }^{41}$ Es el caso de Braymant, donde, sin rechazar la relación posible, parcial, con Abderrahmán, puede pensarse en un derivado de bragmanus, a partir de las historias sobre Alejandro. Cf. F. MARcos MARÍn, "Notas de literatura medieval (Alejandro, Mainete, Marco Polo. . ) desde la investigación lêxica de 'brahmán' y sus variantes", $V R, 36$ (1977), 121-161. (Desarrollaremos algunos datos en nuestro comentario, en $R P h$, al $D C E C$ de J. Corominas y J. A. Pascual, s.v. BRAMANTE).

42 "Egipto y los orígenes de la historiografía árabe-española", RIEI., 5 (1957), 157-249; "Ensayo sobre las aportaciones orientales en la España musulmana y su influencia en la formación de la cultura hispano-árabe", ibid., 9/10 (1961-62), 65-231, y 11/12 (1963-64), 7-141. 
to de partida, para lo cual analiza, en primer lugar, las artes narrativas en esta literatura, con especial atención al período preislámico. Habla así de "la poesía que narra leyendas antiguas", los ayyam al-carab, la leyenda primitiva de Antara, y anticipa el problema central. Este sería el estudio de "la poesía épica en la España musulmana”, donde insiste en el conocimiento en al-Andalus de tradiciones orientales, en el género al-sira, desde la sira del Profeta, importante entre los moriscos españoles, hasta otros tipos célebres de siyar, con un apartado, "al-siyar wa-l-magazi en la España musulmana" en el que atiende a la literatura aljamiada, claro precedente de los estudios de Galmés, uno de cuyos capítulos tiene precisamente este mismo título. Atiende luego a una serie de cantos épicos andalusíes, en los que habla de "desarrollo épico porque versan sobre hechos históricos inseparables ya que uno da lugar al otro de modo que son moldeados todos en un crisol narrativo" 43 , y atiende, finalmente, a las urchuzas históricas, desarrollando la exposición de Ribera y traduciendo parte de la de Ibn Abd Rabbihi, con lo cual atraía la atención sobre ella.

El estudio de las leyendas épicas en la España musulmana, que sigue a los capítulos anteriores, distingue entre las de fondo visigodo (vitizano) y las "cultivadas por la gente arabizada" y relaciona con amplitud hechos de Oriente y Occidente. Junto con los estudios de Makki, este capítulo es punto de partida imprescindible para el estudio de las leyendas épicas en al-Andalus.

En lo que concierne a la "influencia árabe en la épica española", su método, en el que procede poema por poema, y no rasgo por rasgo, supone un grave riesgo, pues es fácil dejarse llevar de apriorismos. Así, es difícil asentir a su idea de que la descripción del camino, tan minuciosa en el Poema del Cid, es un rasgo árabe que coincide con tópicos como el de los campamentos abandonados y las rutas de la amada. Puede haber, y hay, coincidencias; pero falta ese elemento que hemos llamado la modalidad, es decir, las circunstancias concomitantes a la realización de la acción: el Cid es un guerrero desterrado, no un enamorado que reconstruye las huellas del paso del objeto de sus deseos. En otro sentido, cuando se nos dice que las nuevas del Cid son los ahadit o 'hadices' del Cid, estamos de acuerdo, pero esto no tiene que ver con la épica, sino con la penetración lingüística y cultural del árabe; es un problema de calco semántico, no de género literario. En cambio, cuando vemos que el Cid se hace como "hi-

${ }^{43}$ La épica árabe, p. 63. 
jo de sus obras" en el Poema, y que esto es lo fundamental de Antara, tan admirado por el castellano, o que los héroes árabes y los cristianos se autoapellidan ${ }^{44}$ en el combate, para reunir a sus huestes en torno suyo: Yo soy Roy Diaz / Soy el mestizo Antara (p. 102), o que el ángel Gabriel profetiza la victoria al Cid y a Mahoma (antes de la batalla de Badr, conocida en textos aljamiados), o que en los Infantes de Lara, a los que hemos de volver, la interpretación es constante, entonces estamos en una línea prometedora, que debe llevar a una metodología que analice rasgo por rasgo, y no poema por poema.

La línea iniciada por Galmés, en 1967, con el estudio del Libro de las batallas, invierte la perspectiva cronológica, pues arranca de un manuscrito morisco del XVI, en el que se narran cinco batallas, con las cuales se consolida el Islam, las de $\mathrm{Hu}$ naim, al-Jandaq, al-Azyad, el Yemen y el valle de Yarmuk. En todas ellas el héroe se opone al espíritu del mal; hay influencias mágicas del Profeta, de los buenos y malos espíritus, sueños présagos, cuerpos con propiedades maravillosas, traslados fantásticos por espacio y tiempo, que bastarían para negar el aserto de Dozy al que nos referíamos antes, así como una serie de fundamentales rasgos caballerescos: el valor, la fidelidad, el amor a la verdad, la protección a las viudas, huérfanos y pobres, la generosidad, la veneración a las mujeres y la liberalidad, sobre todo respecto a los poetas: el caballero mismo es también poeta.

Pese a la abundancia de elementos ficticios, el texto aljamiado busca una impresión realista. Lo ficticio está como algo necesario para la elaboración poética de los hechos históricos o tradicionales. Este verismo se observa en la fidelidad a topónimos y antropónimos y en el carácter humano del héroe. Este es un ser normal que se eleva por sus virtudes, sobre todo las sociales, aunque no carezca de defectos. La grandeza del héroe, una vez más, radica en su condición de hijo de sus obras. Formalmente, en el libro se combinan lo narrativo y lo dramático, $y$, en menor medida, lo lírico.

El estudio de Galmés nos permite cerrar un ciclo, desde lo preislámico a lo morisco. En el amplio mundo hispánico, la épica castellana quedaría en medio, con posibilidades, relativas, de ver en ella fenómenos que pueden aparecer en la árabe antes y/o después.

En 1968, al presentar los resultados de nuestro estudio sobre "El problema del elemento árabe en los orígenes de la épica es-

${ }^{44}$ F. Marcos Marīn, "El autoapellido en la épica árabe", Bol. Asoc. Esp. Orientalistas (BAEO), 6 (1970), 208-213. 
pañola", pretendíamos sistematizar los puntos tratados en los autores que hemos citado, es decir, el carácter épico de una serie de textos árabes, siempre que épico fuera un término que no tuviera que entenderse exclusivamente al modo homérico, las pruebas del conocimiento en al-Andalus de la materia épica de Oriente, y el desarrollo de materia propia, lo que implicaba el estudio de la urchuza de Ibn Abd Rabbihi, que se traducía por vez primera completa. Metodológicamente, el camino se marcaba en una serie de puntos, que aparecieron reunidos en una breve nota de esta manera ${ }^{45}$ :

"Los medios de comunicación por los que pudieron transmitirse esos rasgos literarios, y si podían existir en la literatura hispánica preárabe.

Los rasgos del héroe: caballerosidad, valor, magnanimidad, astucia, amor, fortaleza, etc.

Las situaciones literarias: sangre, venganza familiar, sumisión al Rey o al Poder central, separación, etc.

Las instituciones: caballería, centralismo, venganza familiar, cojuradores, duelo jurídico, gobierno, asambleas de notables, poder del Rey y poder de la asamblea, etc."

La aplicación de esta metodología temática por Ảlvaro Galmés, en su "Épica árabe y épica castellana", condujo, como no podía ser menos, a conclusiones importantes: sin olvidar la posibilidad de la poligénesis, hay elementos, como la relación entre el Cid y el sayyid árabe, el episodio de los judíos, el código del honor caballeresco árabe, con sus peculiaridades, la palabra como elemento mágico, el autoapellido ${ }^{46}$, la presencia de la mujer en la guerra, la mujer de la familia del vencedor que consuela al cautivo, el enamoramiento de oídas, la guerra santa, la distribución del botín, el ángel Gabriel, o el llanto sobre las cabezas degolladas, arranque de la venganza del Poema de los Infantes de Lara (que recoge elementos árabes ya estudiados por Abd el Badi, como el llanto de Muza ante la de su hijo Abd el Aziz) todos los cuales suponen una directa influencia árabe en los orígenes de la épica castellana.

Simultáneamente, al estudiar los "Elementos árabes en los orígenes de la épica hispánica”, buscamos la ampliación de las fuentes recurriendo a los poemas recogidos en la hamasa. No vamos a detenernos en el planteamiento inicial de nuestro estudio, que recogía problemas de género literario, en primer lugar,

45 "Los origenes de la épica española", p. 158.

${ }^{46} \mathrm{Cf}$. nota $4 \dot{4}$, supra. 
atendía luego a tesis sobre orígenes de la épica, para, al ocuparse de la épica árabe, traducir y comentar detalladamente la urchuza de Ibn Abd Rabbihi, para señalar, a partir de ella, algunos elementos característicos. Todo ello se limitaba, en el fondo, a desarrollar aspectos ya anunciados, y a los que nos hemos referido anteriormente. Tras ellos, y a partir de un cotejo de las fuentes árabes, se estudiaban, con la metodología que hemos resumido arriba, esos elementos árabes en tres apartados, el héroe, el individuo y la sociedad.

En lo concerniente al héroe, junto a la autoafirmación por el autoapellido, a la que nos hemos referido antes, y de la que los textos de la hamasa de Abu Tammam proporcionan más ejemplos, conviene tener en cuenta la concepción distinta de un héroe, como el islámico, que es el medio por el que Dios obra, y de un héroe cristiano, que es ayudado por Dios ${ }^{47}$. El héroe, además, que se nos presenta como hijo de sus obras, está ligado a la dignídad familiar, es corresponsable y solidario con su familia. Pero no acaba todo en el nombre del héroe: los dos elementos fundamentales a su lado, caballo y espada, tienen su propio nombre, tan totalmente ligado al de su dueño que puede conocerse a uno por el otro. El fenómeno no es extraño: Durandarte, héroe del romancero, no es más que la personificación de la espada de Roldán. Lo más interesante es que, como ha demostrado Galmés ${ }^{48}$, las dos célebres espadas de la épica francesa, Almace y Durendal - Durandarte -, tienen nombre árabe. En contraste con el mundo germánico, no aparece la forja maravillosa de la espada, sí, en cambio, el considerarla como honroso botín del combate: así el Cid, Ali Ibn Abu Talib, o el propio Profeta. Héroe, espada y caballo se cubren de sangre, en las gestas castellanas o en este verso de al-Harit b. Hisam b. al-Mugira b. Abd Allah (siglo VII):

Dios sabe que no cejé en mi lucha con ellos antes de que mi caballo estuviese cubierto de espumosa sangre.

${ }^{47}$ Aspectos que tratamos de desarrollar en "Ayuda de Dios y obra de Dios en la primitiva épica hispánica", $H R L(1), 417-425$.

48 "«Les nums d'Almace et cels de Durendal” (Chanson de Roland, v, 2143). Probable origen árabe del nombre de las dos famosas espadas", HRL(1), 229 . 241; artículo en el cual, al final, se precisa un detalle apuntado en nuestra Poesía narratiza árabe: la piedra contra la que, tanto Roldán como Harit alZalim (en el Antara árabe) tratan de romper su espada en la hora de la muerte, es sardónice, "piedra inexistente en los Pirineos", según Galmés. La lista de las espadas de los héroes árabes puede verse en $F$. W. SCHWAR7LOSSE, Die Waffen der alten Arab̉en, Leipzig, 1886, pp. 368 ss., citado por Galmés, p. 231. 
El héroe islámico, como el castellano, sin embargo, sabe evitar la lucha: la astucia tiene también su papel; como el Cid puede obtener beneficio de los judíos, o negociar con calma la rendición de una plaza, o discutir en las cortes de Toledo primero las restituciones materiales y luego la reparación de su honor, los héroes árabes saben también obtener ventajas de la astucia. El héroe puede ser aju-l-hazm, es decir, como traduce Freytag ${ }^{49}$, 'prudens' (lit. 'hermano de la firmeza, o la resolución').

Todo ello conduce a que el héroe tiene un honor privado, aparte del que comparta con su tribu; ese honor, el ${ }^{c} i r d$, que se expresa en el fajr 'jactancia', género literario de autoexaltación, no es extraño a manifestaciones como la del Cid (vv. 2494-2496):

Antes fu minguado, agora rico so, que e aver e tierra e oro e onor, e son mios yernos infantes de Carrion.

El Cid, como Abderrahmán I, o Antara, es, por ello, 'isami, o sea, hijo de sus obras, ideal del héroe árabe, que también puede ser ${ }^{i z a m i}$, es decir, el que conserva una gloria heredada. Sin embargo, en todo caso era conveniente la mesura, pues olvidarla podía tener sangrientas consecuencias.

El héroe no está solo: las relaciones de individuo y sociedad son imprescindibles. Entramos con ello en un punto en el que los rasgos poligenéticos pueden confundirse con las modalidades que apuntan a una interinfluencia: la familia es solidaria con sus miembros; pero es natural que toda sociedad primitiva que pierde un miembro queda debilitada, y debe exigir una compensación, en sangre o pecuniaria. Por ello, si la exaltación personal del héroe se manifiesta en el autoapellido, también la familia se autoapellida, como muestran ejemplos abundantes. También por ello, los signos de protección familiar, como la tienda, o el velo femenino, son inviolables. En relación con la leyenda de los infantes de Lara es conveniente aclarar este segundo extremo: cuando el criado es muerto bajo el mando de doña Lambra, ésta queda deshonrada, al ser el manto signo de protección. El hecho se ha interpretado a la luz del derecho germánico; pero puede no ser así, pues, como nos informa Odette de Puigaudeau ${ }^{50}$, si un enemigo, apremiado por sus perseguidores consigue tomar el ve-

${ }^{49}$ GEORG. GUIL. FREYTAG, Hamasae Carmina, Bonn, t. 1, 1828, t. 2, 1847; pp. 65-66. Más ejemplos en nuestra Poesía narrativa, pp. 222-224.

50 "Arts et coutumes des Maures", Hespéris-Tamuda, VIII, 1967, pp. 162-163. 
lo de la mujer (o poner su mano sobre un soporte de la tienda, aunque no se introduzca bajo ésta), está a salvo.

El resultado típico de las relaciones familiares es la venganza de sangre, pues ésta sirve para mantener la potencia relativa del grupo: "sólo el toro soporta la ofensa", dice el proverbio. F. Corriente ${ }^{51}$, a propósito de la "asabiya, o solidaridad de los miembros del grupo, nos dice (p. 54): "Consecuencia inmediata de la 'asabiya es la venganza de la sangre $\left(t a^{\prime} r\right)$, sagrado deber y derecho de aplicar el talión, que pertenece al más allegado; una vez vengado el muerto, se dice que su sangre no ha corrido como agua, mayor ofensa al beduino que la propia muerte, y se le vuelve a considerar vivo moralmente". La diferencia se marca hasta léxicamente, por ejemplo en la moalaca de al-Harit b. Hilliza al-Yaskuri (v. 30):

Si excaváis entre Milha y al-Saqib, hallaréis muertos y vengados.

Esta venganza era tanto más difícil, cuanto era virtud de generosidad proteger al miembro de la tribu, costase lo que costase, aun siendo, a nuestros ojos, culpable; así, en la moalaca de Zuhayr b. Abi Sulmá al-Muzani ${ }^{52}$ :

Son generosos: con ellos ni el rencoroso consigue su objeto, ni los culpables (de su clan) son entregados.

Si no es posible la venganza inmediata, se guarda la saña hasta que se pueda realizar el talión ${ }^{58}$; durante este tiempo el vengador puede abstenerse de todo goce sensorial, abandonar su aspecto externo, y realizar otro tipo de penitencias o manifesta. ciones de duelo. Un verso de Tabata Sarran, en la hamasa de Abi Tammam ${ }^{54}$, es muy significativo de la importancia del $t a ' r$ :

A éste le sobrevino un sueño extraño; para él la principal preocupación es/la sangre del Talión $\left(t a^{\prime} r\right)$, o lanzarse contra un campeón curtido.

En último término, la ordalía, o juicio de Dios, servía para determinar una responsabilidad dudosa o discutida. Este juicio, con su manifestación específica en el duelo de campeones, informa las gestas árabes, germánicas y románicas, de modo que resulta imposible prescindir de lo que en él pudiera haber de orien-

\footnotetext{
${ }^{51}$ Las mu allaqai: antología y panorama de Arabia preislámica, Madirid, 1974.

${ }^{52}$ Traducción de F. Corriente, íbid., p. 45.

${ }^{53}$ Ejemplos en Poesia narrativa, pp. 252-256.

${ }^{54}$ Ed. Schultens, pp. 406-407, v. 3.
} 
tal. En relación con él está la institución de los cojuradores, es decir, los que juran con el acusado en favor de su inocencia.

Pero el concepto fundamental que domina las relaciones entre individuo y sociedad es la vergüenza, ${ }^{c} a r$. Este concepto incluye el de mantenimiento del honor del grupo con el de sus individuos, implica la ayuda mutua y, si se rompe por ofensa, exige venganza. El signo externo de esa ofensa es la mancha física, y tanto en el mundo árabe como en los fueros castellanos el hecho de manchar intencionadamente implicaba una deshonra, tan grave que, de acuerdo con los fueros ${ }^{55}$, las multas correspondientes equivalen a la debida por maltratar a una mujer (Cuenca), o romper la pierna o derribar a un caballero (Teruel). La relación con la leyenda de los infantes de Lara, donde todos los elementos relacionados con la venganza de sangre, la vergüenza, el honor familiar, la ofensa por mancha física, la violación del sagrado del manto de la dama, están presentes, es inmediata e innegable ${ }^{56}$.

En la vida social, pese a la aparente condición de inferioridad, el papel de la mujer es decisivo. Sin embargo, en la épica, suele ser, cuando se individualiza, un personaje conflictivo: obliga al héroe a realizar difíciles hazañas nor su culpa, o es traidora y causa la perdición de muchos guerreros - o es, como Crimilda, la fuerza del destino que arrastra a miles a la muerte. Es también la bella de la que el héroe se enamora de oídas (o que se enamora, por su parte, como se ve en el juego de la hija del Cid con el moro en el romance del rey Búcar ${ }^{57}$ ), o quien, oor medio de un hijo, proporciona un vengador al prisionero (como Mudarra), o quien lo ayuda a escapar intercambiando con él los vestidos (en las $\mathrm{Mil}$ y una noches, en Bernardo del Carpio). La mujer puede estar presente en el combate, como en el Libro de las Batallas, o en el Poema del Cid, pues así indica a sus defensores el peligro que le supone la derrota, con el consiguiente deshonor del grupo.

El papel de la sociedad va imponiéndose al individuo, a quien impone obligaciones, limitándolo. Al mismo tiempo, se ve inserta en un mundo con el que tiene unà relación dialéctica; en su propio beneficio, busca un modo de dominar el entorno, y cree tenerlo en la magia. Este elemento es importante en la épica, aunque no tanto como en otros géneros (la cuentística, por

\footnotetext{
5s Poesia narratiza, pp. 266-268.

${ }^{56}$ Para una posible relación con las ofensas que hicieron a Mahoma buscar asilo en Medina, cf: Ibn Hisham, Sirah, ed. Ferdinand Wüstenfeld, Göttingen, 1858-1859, y ALFRED GUILLAUME, The life of Muhammad, London, 1955.

${ }^{57}$ Cf. DIEGO CATALÁN, Siete siglos de romancero, Madrid, 1969, pp. 135-215.
} 
ejemplo). Adquiere por ello un sentido especial que un héroe como el Cid, famoso entre los árabes como catador de agüeros, de lo cual abundan los testimonios, los cate precisamente a la manera oriental ${ }^{58}$. En esta línea está también la aparición, ya comentada, del ángel Gabriel, el sueño présago, tan repetido, o cualquier otra de las muchas formas de adivinación.

Dentro de la estructura social medieval, la influencia árabe se ejerce claramente en la institución de la caballería. Los árabes introducen grandes novedades en la monta y doma de los caballos, en su cría, en su uso, en su utilización guerrera, y crean también una institución que hace del caballero un miembro social especialmente distinguido: la base está en el honor individual, y en el concepto de vergüenza, las manifestaciones externas son los combates entre campeones, la protección de los desamparados, el sacrificio, e incluso formas especiales de agruparse, como las órdenes religiosas caballerescas, que calcan modelos musulmanes, a partir de otro concepto fundamental, en el que la influencia musulmana es evidente, como es el de guerra santa. Este último punto informa la mayor parte de la épica medieval, y bien podriamos decir que sin guerra santa no existiría el género, ni ocuparía el lugar literario que ocupa. Por otro lado, en relación con las actividades del caballero, no todo es el caballo, las armas o la guerra; están también los juegos nobles, entre los que descuella el ajedrez, de fundamental importancia en la épica: jugando a él se producen escenas fundamentales, como la revelación de la identidad de Mudarra, varias muertes, en la épica francesa $^{53}$, y multitud de episodios. Otras ocupaciones, como la cetrería, llenan el tiempo resiante, y se reflejan adecuadamente en la canción de gesta.

El símbolo externo de esas reiaciones sociales es, todavía hoy, la bandera. En el uso de banderas y estandartes, en costumbres como enrollarlos al asta de la lanza en el combate, o llevarlos tremolando, para agrupar a su alrededor a los guerreros, en el de clavar el estandarte a una lanza, o dar la bandera como signo de dignidad y mando (el alférez), hay una indudable presencia oriental, pues ya los árabes preislámicos usaban este signo.

Los distintos elementos y ejemplos estudiados en Poesía narrativa árabe y épica hispónica, a los que hemos añadido ahora otros inéditos, y que pueden ampliarse en la misma línea sin dificultad, llevaron, en su día, a una serie de conclusiones: una

\footnotetext{
${ }^{58}$ Poesía narrativa, pp. 282-302.

${ }^{59}$ Ibid., pp. 317-319.
} 
primera etapa correspondería a la formación de las leyendas épicas románicas e hispanoárabes, a partir de una serie de elementos básicos, que incluyen aspectos latinos, germánicos y autóctonos, junto con el influjo oriental, y que corresponden a un período de cantos historiales. De la triple influencia hispano-árabegermánica arrancaría una primitiva épica hispánica, a la que se debe el interés que el tema árabe hispánico tiene en Francia y en el mundo románico general. Francia, que tiene más vivo el influjo germánico, pudo crear una rica poesía épica, en la cual esos elementos hispánicos se diluyen y transforman, y los enriquece hasta el punto de devolverlos al suelo peninsular, donde, por el doble influjo de la épica hispánica y la francesa nace la épica castellana, mientras que la epopeya hispánica se prolonga en las narraciones aljamiadas. El ciclo se cierra con el Romancero y los libros de caballerías.

Galmés de Fuentes plantea también algunas cuestiones formales: preocupado por el problema de la métrica de la épica castellana $^{60}$, llega a pensar que, salvando las distancias, hay una proximidad con la prosa rimada árabe. Habla de una "estructura lineal", que se monta "en el andamio de una especie de $s a \hat{y}^{c}$ o prosa rimada árabe". Resulta difícil de aceptar, pues la prosa rimada es un género muy complicado, culto, y la métrica de las gestas, por lo que sabemos, se mueve en otro tipo de inquietudes y planteamientos formales. Hay suficientes elementos más cercanos, como el cursus, que ponen serios interrogantes a tal relación; sin embargo, no cabe duda de que el metro de las urchuzas, por su sencillez y su proximidad a metros latinos, como el leonino, pudo enlazar con cierta facilidad en las estructuras formales de la épica románica. En todo caso, dadas las diferencias estructurales entre los medios lingüísticos, las relaciones formales requieren demostraciones más precisas.

El punto final de nuestro estudio, en el que podemos prescindir de una serie de aportaciones menores, que van agregando precisiones, limando detalles, sin hacer variar lo fundamental, sería un intento de valoración de la tesis arabista, en el cual, inevitablemente, seremos subjetivos.

El esfuerzo realizado ha presentado una serie de elementos, difíciles de conocer, que aparecen en el mundo árabe y en la épica románica, y que eran familiares a los hispanoárabes. Puede hablarse de una épica árabe (que puede llamarse narrativa, para indicar que no es del tipo homérico), pueden ponerse, al menos,

${ }^{60}$ Épica árabe, pp. 147-150. No se modifica la redacción de 1970. 
en duda elementos adscritos tradicionalmente al mundo germánico, y se revaloriza el papel de la Península ibérica en la formación de las literaturas romances. Al mismo tiempo, a través de lo aljamiado, se detecta la existencia de otra literatura, con sus peculiares valores y sus características especiales, reflejo de una sociedad marginada, pero no por ello despreciable.

En lo que concierne a la pretensión última de los investigadores, también hay diferencias. Abd el Badi se planteaba la reivindicación de un influjo en un campo abandonado, Ribera buscaba un refuerzo del "españolismo" de los andalusíes, y Galmés busca relaciones de tipo más específicamente literario. Por nuestra parte, hemos de confesar, tal vez ingenuamente, que la dedicación a la tesis arabista es, sobre todo, de carácter histórico-cultural, más que literaria: nos parece que los resultados más interesantes son los que contribuyan a explicar el papel de los elementos semíticos en la constitución de la morada vital de los españoles y, por medio de un mejor conocimiento de un importante aspecto de la vida medieval, como es la poesía épica, entender mejor los factores que han determinado la constitución de España.

Universidad Autónoma de Madrid.

FRANCISCO MARCOS MARÎN 